\title{
Adenosine and lidocaine: A new concept in nondepolarizing surgical myocardial arrest, protection, and preservation
}

Geoffrey P. Dobson, PhD

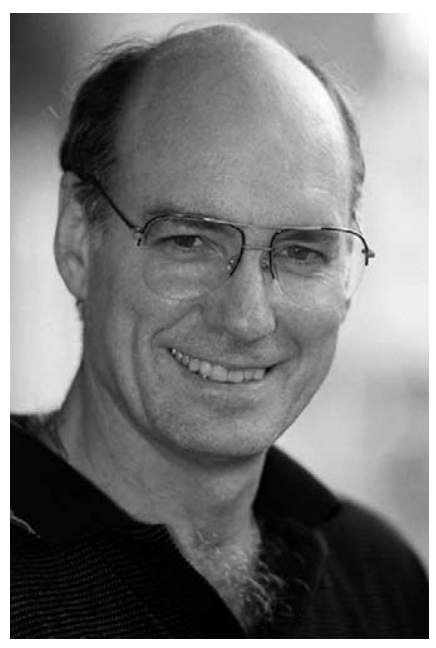

Dr Dobson From the Department of Physiology and
Pharmacology, James Cook University,
Townsville, Queensland, Australia.
This work was supported in part by James
Cook University small grants
6215.93766 .0004 and 6215.94591.2828
and in part by Australian Heart Foundation
grant G00B 0547.
Received for publication March 28, 2003;
revisions requested May 14, 2003; revi-
sions received May 21, 2003; accepted for
publication July 11, 2003.
Address for reprints: Dr G. P. Dobson,
James Cook University, Department of
Physiology and Pharmacology, Molecular
Science Building, Townsville, Queensland
4811 , Australia (E-mail: geoffrey.dobson
@jcu.edu.au).
J Thorac Cardiovasc Surg 2004;127:
794-805

$0022-5223 / \$ 30.00$

Copyright $\odot 2004$ by The American Association for Thoracic Surgery

doi:10.1016/S0022-5223(03)01192-9
Objective: Depolarizing potassium cardioplegia has been increasingly linked to left ventricular dysfunction, arrhythmia, and microvascular damage. We tested a new polarizing normokalemic cardioplegic solution employing adenosine and lidocaine as the arresting, protecting, and preserving cardioprotective combination. Adenosine hyperpolarizes the myocyte by A1 receptor activation, and lidocaine blocks the sodium fast channels.

Methods: Isolated perfused rat hearts were switched from the working mode to the Langendorff (nonworking) mode and arrested for 30 minutes, 2 hours, or 4 hours with $200 \mu \mathrm{mol} / \mathrm{L}$ adenosine and $500 \mu \mathrm{mol} / \mathrm{L}$ lidocaine in Krebs-Henseleit buffer (10 $\mathrm{mmol} / \mathrm{L}$ glucose, $\mathrm{pH} \mathrm{7.7}$, at $37^{\circ} \mathrm{C}$ ) or modified St Thomas' Hospital solution no. 2, both delivered at $70 \mathrm{~mm} \mathrm{Hg}$ and $37^{\circ} \mathrm{C}$ (arrest temperature $22^{\circ} \mathrm{C}$ to $35^{\circ} \mathrm{C}$ ).

Results: Adenosine and lidocaine hearts achieved faster mechanical arrest in $(25 \pm$ 2 seconds, $\mathrm{n}=23)$ compared with St Thomas' Hospital solution hearts $(70 \pm 5$ seconds, $\mathrm{n}=24 ; P=.001)$. After 30 minutes of arrest, both groups developed comparable aortic flow at $\sim 5$ minutes of reperfusion. After 2 and 4 hours of arrest (cardioplegic solution delivered every 20 minutes for 2 minutes at $37^{\circ} \mathrm{C}$ ), only $50 \%$ (4 of 8) and 14\% (1 of 7) of St Thomas' Hospital solution hearts recovered aortic flow, respectively. All adenosine and lidocaine hearts arrested for 2 hours $(\mathrm{n}=7)$ and 4 hours $(n=9)$ recovered $70 \%$ to $80 \%$ of their prearrest aortic flows. Similarly, heart rate, systolic pressures, and rate-pressure products recovered to $85 \%$ to $100 \%$ and coronary flows recovered to $70 \%$ to $80 \%$ of prearrest values. Coronary vascular resistance during delivery of cardioplegic solution was significantly lower $(P<.05)$ after 2 and 4 hours in hearts arrested with adenosine and lidocaine cardioplegic solution compared with hearts arrested with St Thomas' Hospital solution.

Conclusions: We conclude that adenosine and lidocaine polarizing cardioplegic solution confers superior cardiac protection during arrest and recovery compared with hyperkalemic depolarizing St Thomas' Hospital cardioplegic solution.

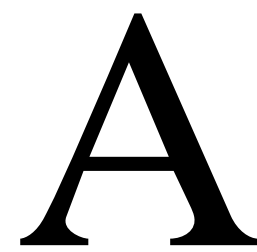

lthough 99\% of all surgical cardioplegic solutions contain depolarizing potassium, typically at concentrations above $15 \mathrm{mmol} /$ $\mathrm{L},{ }^{1,2}$ an increasing number of studies have shown a link between exposure to high potassium and postcardioplegia ionic and metabolic imbalances, myocardial stunning, arrhythmia, ischemic injury, tissue edema, endothelial damage, free radical production, and functional loss during reperfusion. ${ }^{2-4}$ Left ventricular dysfunction is thought to arise from a decrease in adenosine triphosphate (ATP) content, an increase in intracellular $\mathrm{H}^{+}$concentration, and an increased sodium influx via the $\mathrm{Na}^{+} / \mathrm{H}^{+}$ exchanger, which in turn activates the $\mathrm{Na}^{+} / \mathrm{Ca}^{2+}$ exchanger (and possible $\mathrm{Ca}^{2+}$ release from the sarcoplasmic reticulum), which in some cases may lead to a potentially lethal rise in intracellular $\mathrm{Na}^{+}$and $\mathrm{Ca}^{2+}$, mitochondrial damage, apo- 
ptosis, and cell death. ${ }^{3,5-8}$ The increase in intracellular $\mathrm{Na}^{+}$ and loss of $\mathrm{K}^{+}$upon depolarization is believed to activate the energy-dependent ion pumps, thereby increasing energy demands during ischemia.

Alternative strategies to arrest the heart have been sought. ${ }^{3,9}$ One strategy has been to use ATP-sensitive $\mathrm{K}^{+}$ channel openers (pinacidil, nicorandil, or aprikalim), which arrest the heart in diastole by polarizing the membrane and thus minimizing metabolic perturbations, reducing transmembrane fluxes and the possibility of $\mathrm{Na}^{+}$and $\mathrm{Ca}^{2+}$ loading. ${ }^{2-4,9-11}$ Unfortunately, the potential use of $\mathrm{K}^{+}$channel openers in normokalemic cardioplegia in the clinical setting remains problematic. This is due in part to the inconclusive results obtained in a variety of animal models and because many $\mathrm{K}^{+}$channel openers require a carrier such as high concentrations of dimethylsulphoxide or ethanol. ${ }^{11}$

The aim of the present study is to quantify the efficacy of adenosine and lidocaine (AL) as the arresting and protecting combination in a normokalemic Krebs-Henseleit solution $\left(5.9 \mathrm{mmol} / \mathrm{L} \mathrm{K}^{+}\right)$. Adenosine was chosen because of its $\mathrm{K}^{+}$ channel-opening properties, which increase the outward $\mathrm{K}^{+}$ current resulting in hyperpolarization via $\mathrm{A} 1$ receptor stimulation and shortening of the action potential, ${ }^{12}$ and its broad-spectrum cardioprotective actions. ${ }^{13-15}$ Lidocaine was chosen largely because of its local anesthetic properties (via blocking the $\mathrm{Na}^{+}$fast channels and polarizing the myocardial cell membrane and preventing activation of the action potential) $)^{2,16}$ and for its antiarrhythmic effects. ${ }^{17} \mathrm{In}$ addition, adenosine and lidocaine have been shown separately to protect against ischemia, by reducing $\mathrm{Ca}^{2+}$ loading in isolated myocardial and endothelial cells, ${ }^{16,18}$ to scavenge free radicals, and to possess vasodilatory and antiinflammatory properties. ${ }^{15,19,20}$ Hence, the combination of adenosine and lidocaine would arrest the heart by preventing action potential generation and would protect the heart from ischemia-reperfusion injury. Although adenosine added to hyperkalemic blood cardioplegic solution ${ }^{21}$ and $\mathrm{Na}^{+}$fast-channel blockade has been investigated in a number of animal models, ${ }^{22,23}$ no study has investigated adenosine and lidocaine as the sole arresting combination. We report that polarized arrest using normokalemic multidose AL cardioplegia is far superior to depolarized arrest using potassium-based St Thomas' Hospital solution in the working rat heart model over 2 and 4 hours of arrest. We further propose that the beneficial effects appear related to AL's ability to "clamp" the membrane potential near its resting state and additional cardioprotective properties of each drug alone and in combination.

\section{Materials and Methods \\ Animals}

Male Sprague-Dawley rats $(323 \pm 6 \mathrm{~g}, \mathrm{n}=47)$ were obtained from Animal Resources Center (Canningvale, Wash) and James
Cook University's breeding colony. Animals were fed ad libitum and housed in a 12-hour light/dark cycle. On the day of the experiment, rats were anesthetized with an intraperitoneal injection of nembutal (sodium pentabarbitone; $60 \mathrm{mg} / \mathrm{kg}$ body weight) and the hearts rapidly excised (details below). ${ }^{24}$ Rats were handled in compliance with James Cook University Guidelines (ethics approval number A557) and with the Guide for Care and Use of Laboratory Animals, published by the National Institutes of Health (NIH publication 85, revised 1985). Adenosine (A9251 >99\% purity) and all other chemicals were obtained from Sigma Chemical Co (Castle Hill, New South Wales). Lidocaine hydrochloride was purchased as a $2 \%$ solution (ilium) from Pharmaceutical Supplies (Lyppard, Queensland).

\section{Composition of Buffers and Arrest Solutions}

Krebs-Henseleit perfusion buffer: Hearts were perfused in the Langendorff and working mode with a modified Krebs-Henseleit buffer containing $10 \mathrm{mmol} / \mathrm{L}$ glucose, $117 \mathrm{mmol} / \mathrm{L} \mathrm{NaCl}$, $5.9 \mathrm{mmol} / \mathrm{L} \mathrm{KCl}, 25 \mathrm{mmol} / \mathrm{L} \mathrm{NaHCO}_{3}, 1.2 \mathrm{mmol} / \mathrm{L} \mathrm{NaH}_{2} \mathrm{PO}_{4}$, $1.12 \mathrm{mmol} / \mathrm{L} \mathrm{CaCl}_{2}$ (free $\mathrm{Ca}^{2+}=1.07 \mathrm{mmol} / \mathrm{L}$ ), $0.512 \mathrm{mmol} / \mathrm{L}$ $\mathrm{MgCl}_{2}$ (free $\mathrm{Mg}^{2+}=0.5 \mathrm{mmol} / \mathrm{L}$ ), $\mathrm{pH} 7.4$ at $37^{\circ} \mathrm{C}^{24}$ The perfusion buffer was filtered with a $1-\mu \mathrm{m}$ membrane and then bubbled vigorously with $95 \% \mathrm{O}_{2} / 5 \% \mathrm{CO}_{2}$ to achieve a $\mathrm{PO}_{2}$ greater than $600 \mathrm{~mm} \mathrm{Hg}$. The perfusion buffer was not recirculated.

$\mathrm{AL}$ arrest solution: Preliminary studies showed that $200 \mu \mathrm{mol} / \mathrm{L}$ adenosine plus $500 \mu \mathrm{mol} / \mathrm{L}$ lidocaine in $10 \mathrm{mmol} / \mathrm{L}$ glucose containing Krebs-Henseleit buffer $\left(\mathrm{pH} 7.7\right.$ at $37^{\circ} \mathrm{C}$ ) gave optimal arrest and recovery profiles in the rat model (data not shown). The AL arrest solution was filtered with $0.2-\mu \mathrm{m}$ filters and maintained at $37^{\circ} \mathrm{C}$. The arrest solution was not actively bubbled with $95 \% \quad \mathrm{O}_{2} / 5 \% \quad \mathrm{CO}_{2}$, hence the higher $\mathrm{pH}$. The average $\mathrm{PO}_{2}$ of the AL solution was $131 \mathrm{~mm} \mathrm{Hg}$ and the $\mathrm{PCO}_{2}$ was 5 to $10 \mathrm{~mm} \mathrm{Hg}$.

Modified St Thomas' Hospital solution No. 2: The composition of modified St Thomas' solution No. 2 was $\mathrm{NaCl}(110 \mathrm{mmol} / \mathrm{L})$, $\mathrm{KCl}(16 \mathrm{mmol} / \mathrm{L}), \mathrm{MgCl}_{2}(16 \mathrm{mmol} / \mathrm{L}), \mathrm{CaCl}_{2}(1.2 \mathrm{mmol} / \mathrm{L})$, $\mathrm{NaHCO}_{3}(25 \mathrm{mmol} / \mathrm{L})$, and $\mathrm{pH}$ 7.8. The buffer was filtered with $0.2-\mu$ filters and maintained at $37^{\circ} \mathrm{C}$. The solution was not actively bubbled with $95 \% \mathrm{O}_{2} / 5 \% \mathrm{CO}_{2}$ and had an average $\mathrm{PO}_{2}$ of $125 \mathrm{~mm} \mathrm{Hg}$ and a $\mathrm{PCO}_{2}$ of 5 to $10 \mathrm{~mm} \mathrm{Hg}$ ). Glucose was not included in St Thomas' Hospital solution based on the findings of Hearse and colleagues, ${ }^{2,25}$ who showed that glucose (with or without insulin) may be deleterious when used as an additive.

Langendorff and working rat heart preparation: Hearts were rapidly removed from anesthetized rats and immediately placed in ice-cold Krebs-Henseleit buffer. Excess tissue was removed, and the heart was connected via the aorta to a standard Langendorff apparatus and perfused in a retrograde fashion with a perfusion pressure of $90 \mathrm{~cm} \mathrm{H}_{2} \mathrm{O}(68 \mathrm{~mm} \mathrm{Hg}){ }^{26}$ After the pulmonary veins and superior and inferior venae cavae had been tied off to minimize leaks $(<1 \mathrm{~mL} / \mathrm{min})$, the pulmonary artery was cannulated for collection of coronary venous effluent. The preparation was then switched to the working mode and the heart was not placed in a thermostat-regulated jacket so that moderate decreases in temperature during arrest would mimic the clinical drift in myocardial temperature. The preload was preset at $10 \mathrm{~cm} \mathrm{H}_{2} \mathrm{O}(7.6 \mathrm{~mm} \mathrm{Hg})$ and the afterload at $100 \mathrm{~cm}$ 

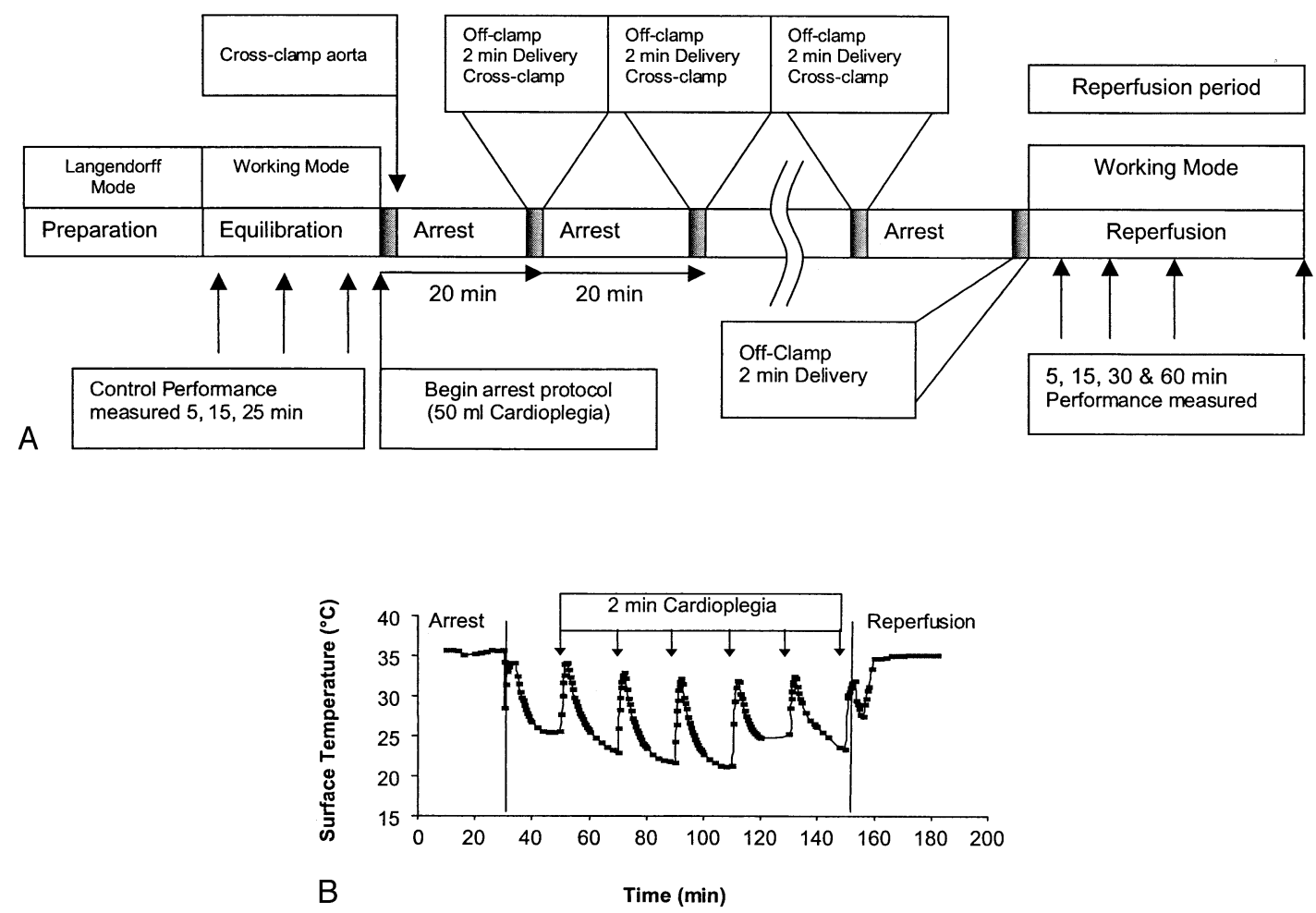

Figure 1. A, Experimental protocol for 30-minute, 2-hour, and 4-hour arrest in the rat heart model. B, Surface temperature profile during arrest. After 30-minute equilibration, hearts were arrested with AL cardioplegic solution or St Thomas' Hospital solution and the aorta clamped. Every 18 minutes the clamp was released and cardioplegic solution delivered for 2 minutes and the clamp reapplied (for 30-minute arrest, a 2-minute pulse was delivered at 15 minutes). Cardioplegic solution was delivered via the aorta at a perfusion head of $70 \mathrm{~mm} \mathrm{Hg}$ and temperature of $37^{\circ} \mathrm{C}$. A 2-minute pulse was administered just before the heart was switched from Langendorff arrest to working mode and recovery was monitored for up to 60 minutes.

$\mathrm{H}_{2} \mathrm{O}(76 \mathrm{~mm} \mathrm{Hg})$. Hearts were stabilized for 30 minutes before being converted back to the Langendorff nonworking mode and before the arrest solution was administered (see below). Heart rate, aortic pressure, coronary flow, aortic flow, and oxygen consumption were measured before, during, and after arrest and are summarized in Figure 1.

Aortic pressure was measured continuously with a pressure transducer (UFI Instruments, Morro Bay, Calif) coupled to a MacLab 2e (ADI Instruments, Richardson, Tex). Systolic and diastolic pressures and heart rate were calculated from the pressure trace using the MacLab software. Arterial and venous perfusate $\mathrm{PO}_{2}$ and $\mathrm{PCO}_{2}, \mathrm{pH}$, and ion concentrations $\left(\mathrm{Ca}^{2+}, \mathrm{Cl}^{-}\right.$, and $\left.\mathrm{Na}^{+}\right)$ were measured with a Ciba-Corning 865 blood gas machine (CibaCorning, Oberlin, Ohio). Coronary flow and aortic flow were measured in volumetric cylinders. Stability studies show that aortic flow decreases $5 \%$ to $10 \%$ per hour over a 2-hour perfusion period at $37^{\circ} \mathrm{C}$ (unpublished observations) and similar to those published by Taegtmeyer and colleagues. ${ }^{27}$ This loss was not taken into account in adjusting aortic flow values during the postarrest reperfusion period (aortic flows reported in this study are those measured directly). The initial criteria for exclusion of working hearts during the 30-minute equilibration period were a heart rate less than 200 beats/min, a systolic pressure less than $100 \mathrm{~mm} \mathrm{Hg}$, and coronary flow less than $10 \mathrm{~mL} / \mathrm{min}$. No pacing or cardiac massage was used during the recovery phase in the working mode. The surface temperature of the heart was measured with a Cole-Parmer thermistor-thermometer (8402-20; Cole-Parmer Instrument Company, Vernon Hills, Ill) every 30 seconds throughout the 2 hours of arrest. The thermistor probe was tucked under the left auricle, and placement in the left heart chamber showed similar profiles as subauricular placement.

\section{Mode of Cardioplegic Delivery and Experimental Protocol}

A 50-mL induction dose of cardioplegic solution was administered via the aorta at $37^{\circ} \mathrm{C}$ and at constant pressure of $70 \mathrm{~mm} \mathrm{Hg}$ with the heart in the Langendorff mode; at the completion of infusion, the aorta was crossclamped with a plastic nontraumatic aortic clip. For the 30-minute arrest protocol, the aorta was crossclamped for 15 minutes, after which it was released to deliver a 2-minute infusion pulse of cardioplegic solution (15-20 mL) and the clamp reapplied. A terminal cardioplegic infusion was repeated once more at 32 minutes before the heart was unclamped and switched to working mode at 34 minutes. For the 2- and 4-hour arrest 
protocols, cardioplegic solution was replenished every 18 minutes with a 2-minute infusion, after which the crossclamp was reapplied. After the terminal cardioplegic infusion, the heart was again switched immediately to the working mode and reperfused with oxygenated glucose-containing Krebs-Henseleit buffer (see Figure 1). The working heart was chosen because the ejecting model is more representative of the natural flow through the heart, whereas the standard Langendorff model receives retrograde flow through the aorta and does no physical work. The Langendorff balloon (nonworking) mode will give systolic and diastolic pressure indices, both of which are preload independent, but the working mode allows one to observe cardiac output and flow under working conditions and to calculate external work, and thereby efficiency. One cannot readily calculate efficiency in the nonworking mode.

\section{Estimation of Myocardial Cell Membrane Potential}

Control (noninjured, nonischemic, prearrest) rat hearts were freeze-clamped at liquid $\mathrm{N}_{2}$ temperatures in the working mode at $37^{\circ} \mathrm{C}(\mathrm{n}=6)$. A separate group $(\mathrm{n}=6)$ was perfused in the working mode and then switched to Langendorff and arrested using St Thomas' Hospital solution No. 2 at $37^{\circ} \mathrm{C}$. A third separate group ( $\mathrm{n}=6$ ) was perfused in the working mode and then switched to the Langendorff mode and arrested using AL cardioplegia. A few minutes after the hearts were arrested, they were freeze-clamped and the left ventricular tissue was ground at liquid $\mathrm{N}_{2}$ temperatures in a mortar. The tissue was then transferred to liquid $\mathrm{N}_{2}$-cooled tubes and kept at $-80^{\circ} \mathrm{C}$ until use.

Cell membrane potential $\left(\mathrm{V}_{\mathrm{M}}\right.$ in millivolts) was calculated from the Nernstian distribution of $\mathrm{K}^{+}$ion between the extracellular and intracellular phases (Equation 1).

$$
V_{M}=E_{K+}=\frac{R T}{z_{K^{+}} F} \times \ln \frac{\left[\mathrm{K}^{+}\right]_{\text {out }}}{\left[\mathrm{K}^{+}\right]_{\mathrm{IN}}}
$$

where $R$ is the universal gas constant $\left(8.31 \mathrm{~J} \mathrm{~mol}^{-1} \mathrm{~K}^{-1}\right), F$ is Faraday's constant $\left(96.49 \mathrm{KJ} \mathrm{mol}^{-1} \mathrm{~V}^{-1}\right), T$ is absolute temperature $(311.15 \mathrm{~K}), z$ is the valence of potassium ion $(+1)$, and $\left[\mathrm{K}^{+}\right]_{\mathrm{IN}}$ and $\left[\mathrm{K}^{+}\right]_{\mathrm{OUT}}$ are the intracellular and extracellular concentrations of $\mathrm{K}^{+}$ion in $\mathrm{mol} / \mathrm{L}$, respectively. ${ }^{24}$ In brief, total tissue potassium $\left(\left[\mathrm{K}^{+}\right]_{\text {TOTAL }}\right)$ was measured on nitric acid-digested freeze-clamped heart tissue $(100 \mathrm{mg})$ by the methods described in Masuda and colleagues. ${ }^{24}$ The $\left[\mathrm{K}^{+}\right]_{\mathrm{IN}}$ was calculated from the following equation: $\left[\mathrm{K}^{+}\right]_{\text {TOTAL }}=x\left[\mathrm{~K}^{+}\right]_{\mathrm{IN}}+y\left[\mathrm{~K}^{+}\right]_{\text {OUT }}$, where $x$ is the intracellular space and $y$ is the extracellular space, respectively. In the perfused working rat heart, the distribution of total tissue water (see below) is $59 \%$ extracellular and $41 \%$ intracellular. ${ }^{24}$ It was assumed that $\left[\mathrm{K}^{+}\right]_{\text {OUT }}$ was equal to the potassium concentration in Krebs-Henseleit $\left(5.9 \mathrm{mmol} / \mathrm{L} \mathrm{K}^{+}\right)$, AL cardioplegic solution $\left(5.9 \mathrm{mmol} / \mathrm{L} \mathrm{K}^{+}\right)$, or St Thomas' Hospital solution No. 2 (16 mmol// $\left.\mathrm{L} \mathrm{K}^{+}\right)$.

\section{Determination of Tissue Water and Hemodynamic Calculations}

Total tissue water (percent) was determined by the difference in wet weight and dry weight divided by wet weight and multiplied by 100 . Powdered tissue from a number of hearts in control, during different times of arrest without reperfusion and after arrest and reperfusion, were dried to a constant weight at $85^{\circ} \mathrm{C}$ for up to 48 hours as described by Dobson and Cieslar. ${ }^{28}$
Coronary vascular resistance (CVR) in megadyne $\cdot$ seconds . $\mathrm{cm}^{-5}$ was calculated during each 2-minute delivery of cardioplegic solution and calculated by dividing delivery pressure by flow (volume/s) using Equation 2:

$$
\mathrm{CVR}=\frac{1333 \times \mathrm{mm} \mathrm{Hg}}{(\mathrm{mL} / \mathrm{s})} \times 10^{-6}
$$

where $1 \mathrm{~mm} \mathrm{Hg}=1333$ dynes $\mathrm{cm}^{-2}$ and $10^{-6}$ is a conversion factor from dynes to megadynes.

Cardiac oxygen consumption, $\mathrm{MVO}_{2}\left(\mu\right.$ mole $\mathrm{O}_{2} / \mathrm{min} / \mathrm{g}$ dry weight heart), was calculated from Equation 3.

$$
\begin{aligned}
\mathrm{MVO}_{2}= & \frac{\left.\left(\mathrm{PaO}_{2}\right)-\mathrm{PvO}_{2}\right)}{\left(B_{p}-V_{p}\right)} \times \frac{\alpha \mathrm{O}_{2}}{22.40} \times \frac{\text { coronary flow }}{\mathrm{g} \text { dry wt }} \times 1000 \\
= & \frac{\mathrm{mm} \mathrm{Hg}}{\mathrm{mm} \mathrm{Hg}} \times \frac{\mathrm{mL} / \mathrm{mL}}{\mathrm{mL} / \mathrm{mmol}} \times \frac{\mathrm{mL} / \mathrm{min}}{\mathrm{g} \text { dry wt }} \times 1000
\end{aligned}
$$

where $\mathrm{PaO}_{2}$ and $\mathrm{PvO}_{2}$ are the partial pressures of oxygen $(\mathrm{mm} \mathrm{Hg})$ in the arterial and venous perfusion lines. $B_{p}$ is the barometric pressure $(760 \mathrm{~mm} \mathrm{Hg})$ and $V_{p}$ is the water vapor pressure at $37^{\circ} \mathrm{C}=47.1 \mathrm{~mm} \mathrm{Hg}$. The molar volume for oxygen at standard temperature and pressure (STP) was $22.40 \mathrm{~mL} / \mathrm{millimole} . \alpha \mathrm{O}_{2}$ is the Bunsen solubility coefficient defined as that volume of oxygen gas dissolved in 1 $\mathrm{mL}$ of solution at a specified temperature reduced to STP $\left(0^{\circ} \mathrm{C}, 760 \mathrm{~mm} \mathrm{Hg}\right){ }^{29}$ The $\alpha \mathrm{O}_{2}$ at $37^{\circ} \mathrm{C}$ for human plasma is $0.024 \mathrm{~mL} / \mathrm{mL}$. ${ }^{30}$ Coronary flow (coronary venous effluent) is measured in milliliters per minute and heart weight is expressed as grams dry weight.

External cardiac work or power output (J/min/g dry weight heart)

$$
\begin{gathered}
=\frac{(\text { aortic }+ \text { coronary flow })\left(\times 10^{-6}\right)}{\text { heart dry weight }} \times \frac{\text { average systolic pressure }}{1} \\
\times \frac{101,325}{760} \\
=\frac{\mathrm{ml} / \mathrm{min} \cdot \mathrm{m}^{3} / \mathrm{mL}}{\mathrm{g} \mathrm{dry} \mathrm{wt}} \times \frac{\mathrm{mm} \mathrm{Hg}}{\mathrm{mm} \mathrm{Hg}}
\end{gathered}
$$

where $10^{6}$ is required to convert $1 \mathrm{~mL}$ into cubic meters and $1 \mathrm{~atm}=760 \mathrm{~mm} \mathrm{Hg}^{2}=101,325$ Newton meters ${ }^{-2}\left(\mathrm{Nm}^{-2}\right)$.

\section{Statistics}

All results are expressed as mean \pm standard error of the mean (SEM). Statistics were performed separately for each of the 30minute, 2-hour, and 4-hour protocols. Two-way analysis of variance (ANOVA) for repeated measures was used to compare discrete variables (eg, coronary resistance, aortic flow, systolic pressures, oxygen consumption, external work) over multiple time points between the AL and St Thomas' Hospital solution treatment groups. The alpha level of significance for all experiments was set at $P<.05$.

\section{Results}

\section{Heart Membrane Potential}

The resting membrane potential for control isolated working rat hearts was $-83 \pm 2 \mathrm{mV}(\mathrm{n}=6)$, which is in agreement 
TABLE 1. Estimates of the membrane potential (in millivolts) in the isolated rat heart before and during arrest by adenosine and lidocaine (AL) cardioplegia $\left(5.9 \mathrm{mmol} / \mathrm{L} \mathrm{K}^{+}\right)$, hyperkalemic St Thomas' Hospital solution no. 2 (16 mmol/L $\mathrm{K}^{+}$), or $16 \mathrm{mmol} / \mathrm{L} \mathrm{KCl}$ at $37^{\circ} \mathrm{C}$

\begin{tabular}{|c|c|c|c|c|}
\hline Treatment & $\mathbf{n}$ & $\begin{array}{c}\text { Cell } \\
\text { membrane } \\
\text { potential } \\
(\mathrm{mV})^{*}\end{array}$ & $\begin{array}{c}\text { Published } \\
\text { values (mV) }\end{array}$ & Reference \\
\hline $\begin{array}{l}\text { Normal prearrest } \\
\text { controls }\end{array}$ & 6 & $-83 \pm 2$ & $\begin{array}{l}-84 \pm 2 \ddagger \\
-84 \pm 1 \S\urcorner\end{array}$ & $\begin{array}{l}\text { Masuda and } \\
\text { colleagues }^{24} \\
\text { Kleber }^{31}\end{array}$ \\
\hline $\begin{array}{c}\text { St Thomas' Hospital } \\
\text { solution No. } 2\end{array}$ & 6 & $-48 \pm 3$ & $-50 \S$ & Chambers $^{32}$ \\
\hline $\begin{array}{c}16 \mathrm{mmol} / \mathrm{L} \mathrm{KCl} \\
\left(8^{\circ} \mathrm{C}\right)\end{array}$ & 7 & & $-50 \S$ & $\begin{array}{l}\text { Snabaitis and } \\
\text { colleagues }^{22}\end{array}$ \\
\hline $16 \mathrm{mmol} / \mathrm{L} \mathrm{KCl}$ & 6 & & $-49.5 \pm 1 \S^{\prime} \emptyset$ & Kleber 31 \\
\hline AL cardioplegiat & 6 & $-83 \pm 2$ & & This study \\
\hline
\end{tabular}

All values are mean \pm SEM.

*This study. The membrane potential was calculated from the Nernstian distribution of $\mathrm{K}^{+}$ion between intracellular and extracellular phases of left ventricle (see Materials and Methods).

†Adenosine $(200 \mu \mathrm{mol} / \mathrm{L})$ and lidocaine $(500 \mu \mathrm{mol} / \mathrm{L})$ arresting combination was in $10 \mathrm{mmol} / \mathrm{L}$ glucose-containing Krebs-Henseleit solution $\mathrm{pH} 7.4$ (see Materials and Methods).

$\ddagger$ Healthy (noninjured) prearrest perfused isolated rat hearts in the working mode.

§Measured using $3 \mathrm{mmol} / \mathrm{L} \mathrm{KCl}$ microelectrodes.

ๆlsolated perfused guinea pig heart.

with other published values for rat heart ${ }^{24}$ and isolated guinea pig heart ${ }^{31}$ (Table 1). The membrane potential for rat hearts arrested with St Thomas' Hospital solution No. 2 was $-48 \pm 3 \mathrm{mV}(\mathrm{n}=6)$, similar to published values measured with microelectrodes ${ }^{32}$ and to values in hearts arrested with $16 \mathrm{mmol} / \mathrm{L} \mathrm{KCl}$ alone for both $\mathrm{rat}^{22}$ and guinea pig ${ }^{31}$ (Table 1). The membrane potential calculated for rat hearts arrested with AL cardioplegic solution was $-83 \pm 2 \mathrm{mV}(\mathrm{n}=6)$.

\section{Control Perfusion, Times to Arrest, and Arrest Temperature}

During the prearrest (or control period) there was no significant difference in functional parameters between the 2 groups tested in the 30-minute, 2-hour, and 4-hour arrest series (Tables 2, 3, and 4). Hearts receiving AL cardioplegic solution achieved electrical and mechanical arrest in $25 \pm 2$ seconds $(\mathrm{n}=23)$ compared with $70 \pm 5$ seconds $(\mathrm{n}=24)$ for St Thomas' Hospital solution hearts (Figure 2). After delivery of the $50-\mathrm{mL}$ induction volume of cardioplegic solution, 9 of $23 \mathrm{AL}$ hearts experienced an average of $1.3 \pm$ 0.2 escape beats followed by total arrest. St Thomas' Hospital solution hearts arrested progressively (based on the developed aortic pressure) over a longer period of time without appearance of escape beats (Figure 2).
A representative profile of the myocardial surface temperature for either AL hearts or St Thomas' Hospital solution hearts is shown in Figure 1, B. During the control and 1-hour reperfusion periods, heart temperature was $37^{\circ} \mathrm{C}$, but during the arrest period myocardial temperature cycled between $35^{\circ} \mathrm{C}$ and $22^{\circ} \mathrm{C}$. This cycling occurred because the heart was not placed in a temperature-controlled jacket and the peak temperatures correspond to the 2-minute delivery of cardioplegic solution at $37^{\circ} \mathrm{C}$ and the valleys correspond to the end of the 18-minute intervening ischemic period. The average heart temperature over 2 hours of arrest was $28^{\circ} \mathrm{C}$ to $30^{\circ} \mathrm{C}$ and was not different between $\mathrm{AL}$ and $\mathrm{St}$ Thomas' Hospital solution hearts (Figure 1, B). However, we acknowledge that normothermic delivery of St Thomas' Hospital cardioplegic solution differs from its current clinical use, but this strategy allowed us to test the limits of AL at higher temperatures, which are becoming the preferred practice in cardiac surgery.

\section{Cardioplegia Delivery Volumes, Coronary Vascular}

Resistance, and $\mathrm{O}_{2}$ Consumption during 2-Minute OffClamp

The total volume of cardioplegic solution delivered over 4 hours to AL hearts was $273 \mathrm{~mL}$ and $201 \mathrm{~mL}$ for St Thomas' Hospital solution hearts. For example, at 240 minutes of arrest, $17 \mathrm{~mL}$ of cardioplegic solution was delivered to $\mathrm{AL}$ hearts and $7.3 \mathrm{~mL}$ to St Thomas' Hospital solution hearts. CVR during the infusions of cardioplegic solution in the 2and 4-hour arrest series is shown in Figure 3, A. After the terminal delivery in the 2-hour arrest series, AL hearts had significantly lower CVR than the St Thomas' Hospital solution hearts $(P<.05)$, which is consistent with the greater volumes of cardioplegic solution.

Oxygen consumption during infusions of cardioplegic solution was significantly greater in the AL group than in the St Thomas' Hospital solution group in the 2- and 4-hour arrest series (Figure 3,B). The higher oxygen consumption (1.5-3 times baseline) was due to both an increase in perfusate aortic-coronary venous $\mathrm{Po}_{2}$ difference $(83 \pm 1.6 \mathrm{~mm}$ $\mathrm{Hg}$ for AL hearts and $62 \pm 1.9 \mathrm{~mm} \mathrm{Hg}$ for St Thomas' Hospital solution hearts in the 4-hour arrest series) and greater coronary arterial flows in AL hearts. At present, it is difficult to determine whether vasodilation is the primary cause of the differences in oxygen consumption between the 2 groups, although it is noteworthy that vasodilation by itself does not increase oxygen consumption unless there is a flow limitation. During infusions of cardioplegic solution, oxygen consumption in AL and St Thomas' Hospital solution hearts decreased to $10 \%$ and $5 \%$ of their prearrest baseline, respectively.

\section{Functional Profiles during Recovery}

Hearts arrested for 30 minutes with AL cardioplegic solution or modified St Thomas' Hospital cardioplegic solution 
TABLE 2. Functional parameters of isolated working rat hearts during prearrest and reperfusion following 30-minute arrest with adenosine-lidocaine (AL) cardioplegia or modified St Thomas' Hospital solution (St T)

\begin{tabular}{|c|c|c|c|c|c|c|c|}
\hline $\begin{array}{l}\text { 30-minute arrest } \\
\text { protocol }\end{array}$ & Treatment & $\mathbf{n}$ & $\begin{array}{l}\text { Heart rate } \\
\text { (beats/min) }\end{array}$ & $\begin{array}{c}\text { Aortic flow } \\
\text { (mL/min) }\end{array}$ & $\begin{array}{c}\text { Coronary flow } \\
(\mathrm{mL} / \mathrm{min})\end{array}$ & $\begin{array}{c}\text { Rate pressure } \\
\text { product (mm } \\
\mathrm{Hg} / \mathrm{min})\end{array}$ & $\begin{array}{c}\mathrm{O}_{2} \text { consumption } \\
(\mu \mathrm{mol} / \mathrm{min} / \mathrm{g} \text { dry } \\
{\text { weight })^{*}}^{*}\end{array}$ \\
\hline \multirow[t]{2}{*}{ 5-min prearrest } & $A L$ & 7 & $245 \pm 11$ & $34.3 \pm 3.6$ & $21.6 \pm 2.0$ & $31504 \pm 1650$ & $47.3 \pm 4.8$ \\
\hline & St T & 9 & $276 \pm 12$ & $32.8 \pm 2.1$ & $19.4 \pm 1.6$ & $34090 \pm 1110$ & $44.7 \pm 4.2$ \\
\hline \multirow[t]{2}{*}{ 15-min recovery } & $\mathrm{AL}$ & 7 & $225 \pm 19$ & $29.2 \pm 3.2$ & $17.1 \pm 1.8$ & $28228 \pm 2015$ & $52.0 \pm 11$ \\
\hline & St T & 9 & $256 \pm 10$ & $24.8 \pm 2.4$ & $17.0 \pm 1.6$ & $31131 \pm 1267$ & $33.2 \pm 6.7$ \\
\hline \multirow[t]{2}{*}{ 30-min recovery } & $\mathrm{AL}$ & 7 & $237 \pm 14$ & $29.6 \pm 2.8 \dagger$ & $16.5 \pm 1.5$ & $29403 \pm 1231$ & $44.7 \pm 4.3$ \\
\hline & St T & 9 & $255 \pm 12$ & $22.3 \pm 3.3$ & $17.1 \pm 1.2$ & $31154 \pm 1464$ & $40.2 \pm 4.0$ \\
\hline \multirow[t]{2}{*}{ 60-min recovery } & $\mathrm{AL}$ & 7 & $245 \pm 11$ & $22.4 \pm 3.5$ & $15.5 \pm 0.5$ & $29269 \pm 1239$ & $48.2 \pm 6.2$ \\
\hline & St T & 9 & $258 \pm 14$ & $17.0 \pm 3.1$ & $15.4 \pm 1.2$ & $30392 \pm 1727$ & $39.1 \pm 2.8$ \\
\hline
\end{tabular}

*To convert from $\mu \mathrm{mol} / \mathrm{min} / \mathrm{g}$ dry weight to wet weight divide by 7.46 for both prearrest groups and by 9.26 (AL hearts) and 7.41 (St Thomas' Hospital solution hearts) in recovery (see text for details).

$\dagger P<.05$ signifies significance between $\mathrm{AL}$ and St Thomas' Hospital solution groups.

TABLE 3. Functional parameters of isolated working rat hearts during prearrest and reperfusion following 2-hour arrest with adenosine-lidocaine (AL) cardioplegia or modified St Thomas' Hospital solution (St T)

\begin{tabular}{|c|c|c|c|c|c|c|c|}
\hline $\begin{array}{l}\text { 2-hour arrest } \\
\text { protocol }\end{array}$ & Treatment & $\mathbf{n}$ & $\begin{array}{l}\text { Heart rate } \\
\text { (beats/min) }\end{array}$ & $\begin{array}{c}\text { Aortic flow } \\
(\mathrm{mL} / \mathrm{min})\end{array}$ & $\begin{array}{l}\text { Coronary flow } \\
\text { (mL/min) }\end{array}$ & $\begin{array}{c}\text { Rate pressure } \\
\text { product (mm } \\
\mathrm{Hg} / \mathrm{min})\end{array}$ & $\begin{array}{c}\mathbf{O}_{2} \text { consumption } \\
(\mu \mathrm{mol} / \mathrm{min} / \mathrm{g} \text { dry } \\
{\text { weight })^{*}}^{*}\end{array}$ \\
\hline \multirow[t]{2}{*}{ 5-min prearrest } & $\mathrm{AL}$ & 7 & $259 \pm 20$ & $33.2 \pm 2.7$ & $17.1 \pm 1.8$ & $30998 \pm 2046$ & $45.3 \pm 4.30$ \\
\hline & St T & 8 & $259 \pm 13$ & $34.5 \pm 2.1$ & $18.0 \pm 1.3$ & $31329 \pm 1720$ & $46.1 \pm 2.60$ \\
\hline \multirow[t]{2}{*}{ 15-min recovery } & $\mathrm{AL}$ & 7 & $215 \pm 24$ & $17.0 \pm 3.6$ & $15.3 \pm 1.4$ & $24934 \pm 2506$ & $53.6 \pm 7.2$ \\
\hline & St T & 8 & $108 \pm 32 \dagger$ & $5.9 \pm 3.8$ & $7.3 \pm 2.9 \dagger$ & $9514 \pm 3737 \dagger$ & $16.4 \pm 6.6$ \\
\hline \multirow[t]{2}{*}{ 30-min recovery } & $\mathrm{AL}$ & 7 & $248 \pm 22$ & $25.5 \pm 2.3$ & $15.4 \pm 1.6$ & $28722 \pm 2149$ & $51.6 \pm 5.6$ \\
\hline & St T & 8 & $148 \pm 47 \dagger$ & $9.4 \pm 7.0 \dagger$ & $8.93 \pm 4.6$ & $12498 \pm 6863 \dagger$ & $18.9 \pm 7.5$ \\
\hline \multirow[t]{2}{*}{ 60-min recovery } & $\mathrm{AL}$ & 7 & $245 \pm 26$ & $24.6 \pm 2.7$ & $13.8 \pm 1.7$ & $27958 \pm 2457$ & $49.8 \pm 6.5$ \\
\hline & St T & 8 & $147 \pm 45 \dagger$ & $7.7 \pm 5.9 \dagger$ & $8.35 \pm 4.4$ & $11808 \pm 6533 \dagger$ & $18.8 \pm 7.8$ \\
\hline
\end{tabular}

${ }^{*}$ To convert from $\mu \mathrm{mol} / \mathrm{min} / \mathrm{g}$ dry weight to wet weight divide by 7.46 for both prearrest groups and by 9.26 (AL hearts) and 7.41 (St Thomas' Hospital solution hearts) in recovery (see text for details).

†Significance between treatment groups $P<.05$.

spontaneously recovered electrical activity in $\sim 2$ minutes, and by 5 minutes all hearts recovered about $60 \%$ of prearrest aortic flow (Figure 4, $A$ ). Although both groups continued to increase aortic flows in the first 15 minutes of reperfusion, St Thomas' Hospital solution hearts began to decrease flow after 15 minutes and averaged $65 \%$ of baseline at 30 minutes of reperfusion. In contrast, AL hearts after 30 minutes of reperfusion generated significantly greater aortic flows than St Thomas' Hospital solution hearts $(87 \%$ of prearrest values, $P<.05)$. At 60 minutes, aortic flow in St Thomas' Hospital solution hearts decreased to about $\sim 50 \%$ prearrest values while AL hearts decreased to $70 \%$ of baseline values without group differences (Figure $4, A$ ). Peak systolic pressure and external cardiac work also recovered quickly in the first 5 minutes, with higher values in AL hearts, but the differences were not significant (Figure $4, B$ and $C$ ). Similarly, there were no significant differences in recovery of coronary flow, heart rate, rate-pressure product, or oxygen consumption between the 2 cardioplegia groups in the 30-minute arrest series (Table 2).
In contrast to the 30-minute arrest series, hearts arrested for 2 and 4 hours displayed very different recovery profiles. St Thomas' Hospital solution hearts showed significantly lower functional recoveries during and at the end of reperfusion. Mean aortic flow at the end of reperfusion was approximately $22 \%$ and $5 \%$ to $10 \%$ of prearrest values after 2 and 4 hours of arrest, respectively (Figure 4, A). Similarly, systolic pressures at the end of reperfusion were 70 and 30 $\mathrm{mm} \mathrm{Hg}$ for 2- and 4-hour arrest, respectively (Figure 4, B), and external work averaged 13 and $4.0 \mathrm{~J} \mathrm{~min}^{-1} \mathrm{~g}^{-1}$ dry weight, respectively (Figure 4,C). For the 2-hour St Thomas' Hospital solution group, heart rate, coronary flow, rate-pressure product, and oxygen consumption recovered to $40 \%$ to $50 \%$ of their prearrest values after reperfusion (Table 3). After 60 minutes of reperfusion, the 4-hour St Thomas' Hospital solution group could generate only $32 \%$ of the prearrest heart rate, $23 \%$ of systolic pressure, $5 \%$ of aortic flow, $16 \%$ of coronary flow, $14 \%$ of rate-pressure product, and $6 \%$ of the prearrest external cardiac work (Figure 4, Table 4). In direct contrast, rat hearts arrested 

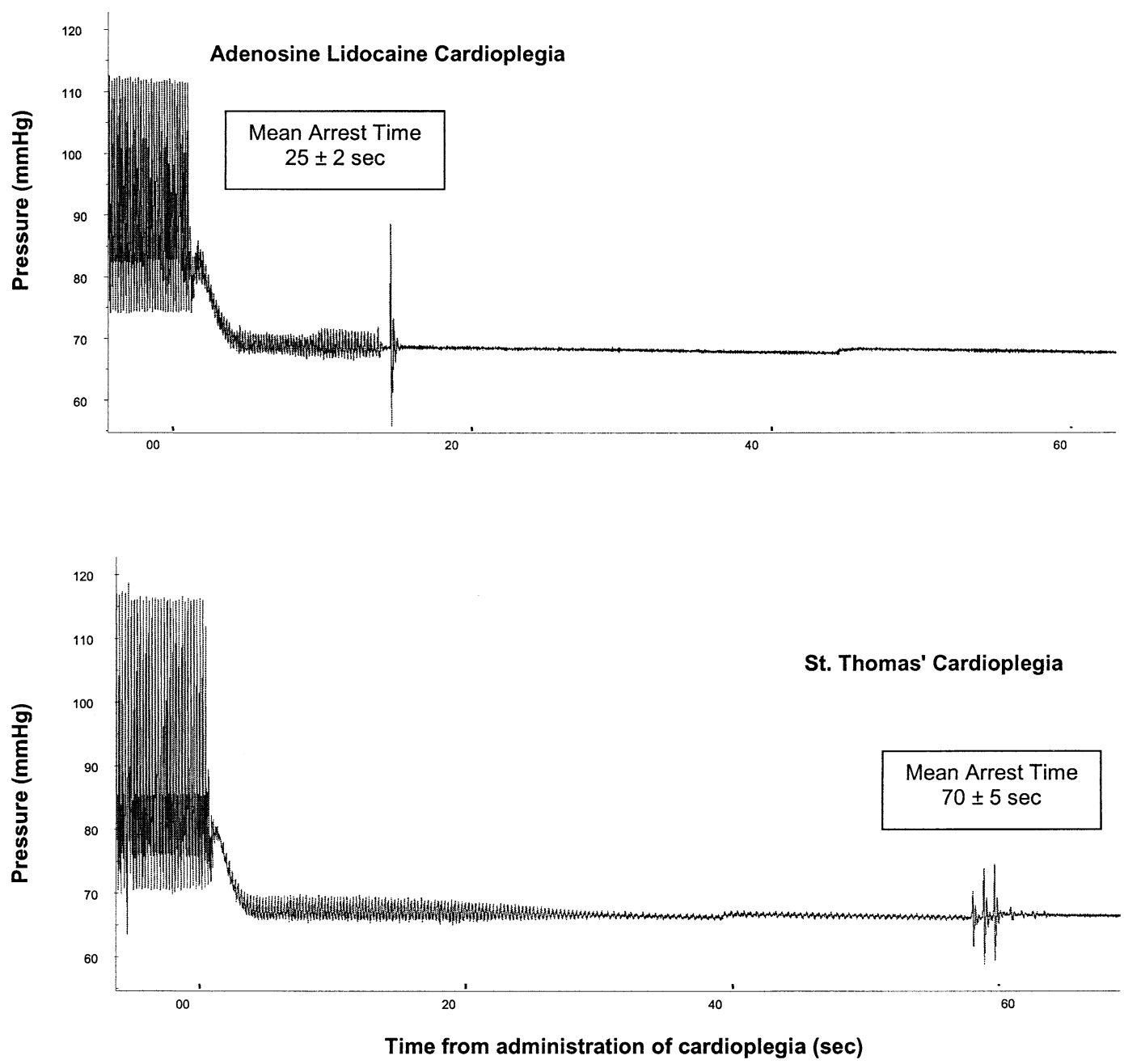

Figure 2. A representative record of time to electromechanical arrest using AL cardioplegic solution and modified St Thomas' Hospital solution No. 2. The average arrest time for AL hearts was $25 \pm 2$ seconds $(n=23)$ and St Thomas' Hospital solution hearts $70 \pm 5$ seconds $(n=24)$. In the St Thomas' Hospital solution hearts a few beats just before arrest were common in this group (shown here $\sim 60$ seconds), but they were not normally as strong as indicated here.

with AL cardioplegic solution for 2 and 4 hours recovered up to $77 \%$ and $70 \%$ of their prearrest aortic flows after reperfusion, respectively (Figure 4, A). AL hearts arrested for 2 and 4 hours also recovered systolic pressures, external cardiac work, oxygen consumption rates, and rate-pressure products to $85 \%$ to $100 \%$ of their prearrest values (Figure 4, $B$ and $C$, and Tables 3 and 4 ).

Total tissue water content measured in separate sham control rat hearts exposed to the prearrest working mode averaged $86.6 \% \pm 1.1 \%(n=4)$, values consistent with our earlier studies. ${ }^{24}$ Total tissue water content in the St Thomas' Hospital solution and AL hearts measured in separate hearts at different times during the 2- and 4-hour arrest periods (without reperfusion) averaged $87 \% \pm 0.8 \%(\mathrm{n}=$ $8)$ and $88.7 \% \pm 0.3 \%(\mathrm{n}=14)$, respectively $(P<.05)$.
However, there were no significant differences found within each cardioplegia group during the 30-minute, 2-hour, or 4-hour arrest protocols. Separate measurements on different hearts were also made after reperfusion. The average values during 60-minute reperfusion were $86.5 \pm 0.6 \%(\mathrm{n}=14)$ and $89.2 \pm 0.3 \%(\mathrm{n}=20)$ for St Thomas' Hospital solution and AL hearts, respectively, after 4-hour arrest. As during arrest without reperfusion, AL hearts had significantly higher postreperfusion water contents than St Thomas' Hospital solution hearts $(P<.05)$; however, there was no correlation between tissue water gain and the differences in functional recovery.

In summary, only 50\% of St Thomas' Hospital solution hearts (4/8) arrested for 2 hours could develop aortic flow against an afterload of $100 \mathrm{~cm} \mathrm{H}_{2} \mathrm{O}$, and that percentage 
TABLE 4. Functional parameters of isolated working rat hearts during prearrest and reperfusion following 4-hour arrest with adenosine-lidocaine (AL) cardioplegia or modified St Thomas' Hospital solution (St T)

\begin{tabular}{|c|c|c|c|c|c|c|c|}
\hline $\begin{array}{l}\text { 4-hour arrest } \\
\text { protocol }\end{array}$ & Treatment & $\mathbf{n}$ & $\begin{array}{l}\text { Heart rate } \\
\text { (bpm) }\end{array}$ & $\begin{array}{c}\text { Aortic flow } \\
\text { (mL/min) }\end{array}$ & $\begin{array}{l}\text { Coronary flow } \\
\text { (mL/min) }\end{array}$ & $\begin{array}{c}\text { Rate pressure } \\
\text { product (mm } \mathrm{Hg} / \\
\mathrm{min})\end{array}$ & $\begin{array}{c}\mathbf{O}_{2} \text { consumption } \\
(\mu \mathrm{mol} / \mathrm{min} / \mathrm{g} \text { dry weight })^{*}\end{array}$ \\
\hline \multirow[t]{2}{*}{ 5-minute prearrest } & $A L$ & 9 & $275 \pm 13$ & $36.5 \pm 1.7$ & $16.28 \pm 1.0$ & $32338 \pm 1084$ & $50.3 \pm 3.4$ \\
\hline & St T & 7 & $259 \pm 13$ & $41.2 \pm 4.2$ & $16.03 \pm 1.3$ & $31508 \pm 1672$ & $57.2 \pm 1.8$ \\
\hline \multirow[t]{2}{*}{ 15-minute recovery } & $A L$ & 9 & $229 \pm 16$ & $19.8 \pm 3.6$ & $13.9 \pm 1.5$ & $25327 \pm 1555$ & $55.0 \pm 6.4$ \\
\hline & St T & 7 & $67 \pm 28 \dagger$ & $2.7 \ddagger$ & $2.3 \dagger$ & $3815 \pm 3040 \dagger$ & $5.7 \pm 5.1 \dagger$ \\
\hline \multirow[t]{2}{*}{ 30-minute recovery } & $\mathrm{AL}$ & 9 & $239 \pm 19$ & $24.6 \pm 2.9$ & $11.5 \pm 1.0$ & $26684 \pm 1669$ & $45.7 \pm 4.1$ \\
\hline & St T & 7 & $79 \pm 26 \dagger$ & $2.4 \dagger$ & $2.9 \ddagger$ & $4137 \pm 3170 \dagger$ & $6.1 \pm 5.5 \dagger$ \\
\hline \multirow[t]{2}{*}{ 60-minute recovery } & $\mathrm{AL}$ & 9 & $249 \pm 17$ & $25.6 \pm 3.3$ & $11.4 \pm 1.3$ & $27569 \pm 1577$ & $44.6 \pm 4.8$ \\
\hline & St T & 7 & $83 \pm 30 \dagger$ & $2.1 \dagger$ & $2.6 \dagger$ & $4359 \pm 3527 \dagger$ & $7.1 \pm 6.5 \dagger$ \\
\hline
\end{tabular}

${ }^{*}$ To convert from $\mu \mathrm{mol} / \mathrm{min} / \mathrm{g}$ dry weight to wet weight divide by 7.46 for both prearrest groups and by 9.26 (AL hearts) and 7.41 (St Thomas' Hospital solution hearts) in recovery (see text for details).

tSignificance between treatment groups $P<.001$.

$\ddagger$ Significance between treatment groups $P<.05$.

decreased to $17 \%$ ( 1 of 7 ) in the 4-hour arrest series (Figure 5). In sharp contrast, $100 \%$ of hearts arrested with $\mathrm{AL}$ cardioplegic solution recovered aortic flow against $100 \mathrm{~cm}$ $\mathrm{H}_{2} \mathrm{O}$ after 2 hours $(\mathrm{n}=7)$ and 4 hours $(\mathrm{n}=9)$ (Figure 5).

\section{Discussion}

Our study shows that the arresting combination of 200 $\mu \mathrm{mol} / \mathrm{L}$ adenosine and $500 \mu \mathrm{mol} / \mathrm{L}$ lidocaine (AL) in normokalemic Krebs-Henseleit buffer at $\mathrm{pH} 7.4$ and $37^{\circ} \mathrm{C}$ is far superior to hyperkalemic St Thomas Hospital solution during prolonged ( 2 or 4 hours) arrest. Rat hearts arrested with multidose AL cardioplegiac soltuion showed: (1) significantly faster electromechanical arrest times (25 vs 70 seconds, $P<.05$ ); (2) lower coronary vascular resistance during cardioplegic infusions (Figure 3); (3) superior recovery of left ventricular function after prolonged arrest (Figure 4, Tables 3 and 4); and (4) a polarized membrane potential of $-83 \mathrm{mV}$ (Table 1). The agreement between the membrane potential estimated from the steady-state extracellular and intracellular phase distribution of $\mathrm{K}^{+}$ions, and microelectrode techniques shows that the heart membrane potential is predominately a potassium equilibrium potential where the sum of the electrical and chemical concentration forces on the ion is zero $\left(\Delta \mathrm{G}_{\mathrm{K}+}=0\right){ }^{24}$ To our knowledge, $\mathrm{AL}$ has not been used as the sole arresting and cardioprotective combination in either normokalemic cardioplegic solutions or longer-term normokalemic preservation solutions.

Although the mechanisms of cardioprotection of $\mathrm{AL}$ cardioplegia were not investigated in the present study, possible reasons for AL's superiority over modified St Thomas' Hospital solution may include the following.

1. AL exhibits better preservation of ATP and phosphocreatine, glycogen stores, and maintenance of a high cytosolic phosphorylation $\left([\mathrm{ATP}] /[\mathrm{ADP}]\left[\mathrm{P}_{\mathrm{i}}\right]\right)$ ratio,
$\Delta \mathrm{G}_{\mathrm{ATP}}^{\prime}$, and low redox (lactate/pyruvate) ratios during arrest, ischemia, and reperfusion.

2. Adenosine's ability to activate A1 receptor subtype and slow the sinoatrial nodal pacemaker rate (negative chronotropy), delay atrioventricular (AV) nodal impulse conduction (negative dromotropy), and reduce atrial contractility (negative inotropy) will contribute to arresting the heart. ${ }^{33}$ Adenosine A1 receptors (and possibly A3 receptors) are also known to confer protection via inhibitory $G$ protein-coupled pathways, which in some instances have been linked to the opening of sarcolemmal ATP-sensitive $\mathrm{K}^{+}$channels. ${ }^{19,34-36}$ More recently, adenosine A1 receptor activation has been linked to new cardioprotective targets including the mitochondria ${ }^{36-38}$ and sarcoplasmic reticulum. ${ }^{39}$ A1 receptor activation is also implicated in adenosine's ability to blunt the stimulatory effects of catecholamines and inhibition of norepinephrine release from nerve terminals. ${ }^{15}$

3. A third factor for the superiority of AL cardioplegic solution is lidocaine's ability to close $\mathrm{Na}^{+}$-fast channels in the atria and ventricles and thereby inhibit the phase 0 upstroke of the action potential and subsequent action potentials. ${ }^{2}$ Although the precise mechanisms of lidocaine's action with the ion-conducting pore are not fully known, ${ }^{40}$ the $\mathrm{Na}^{+}$channel blocker effectively "clamps" the cell membrane near or at its resting membrane potential and, as fewer ion channels or pumps are activated at polarized potentials, the drug may reduce energy-dependent activity and thereby have energy-sparing effects. In addition, lidocaine may act alongside adenosine to further reduce $\mathrm{Na}^{+}$ and $\mathrm{Ca}^{2+}$ loading. ${ }^{6,16,18}$ The possibility also exists that lidocaine in combination with adenosine may exert additional arresting and cardioprotective actions 

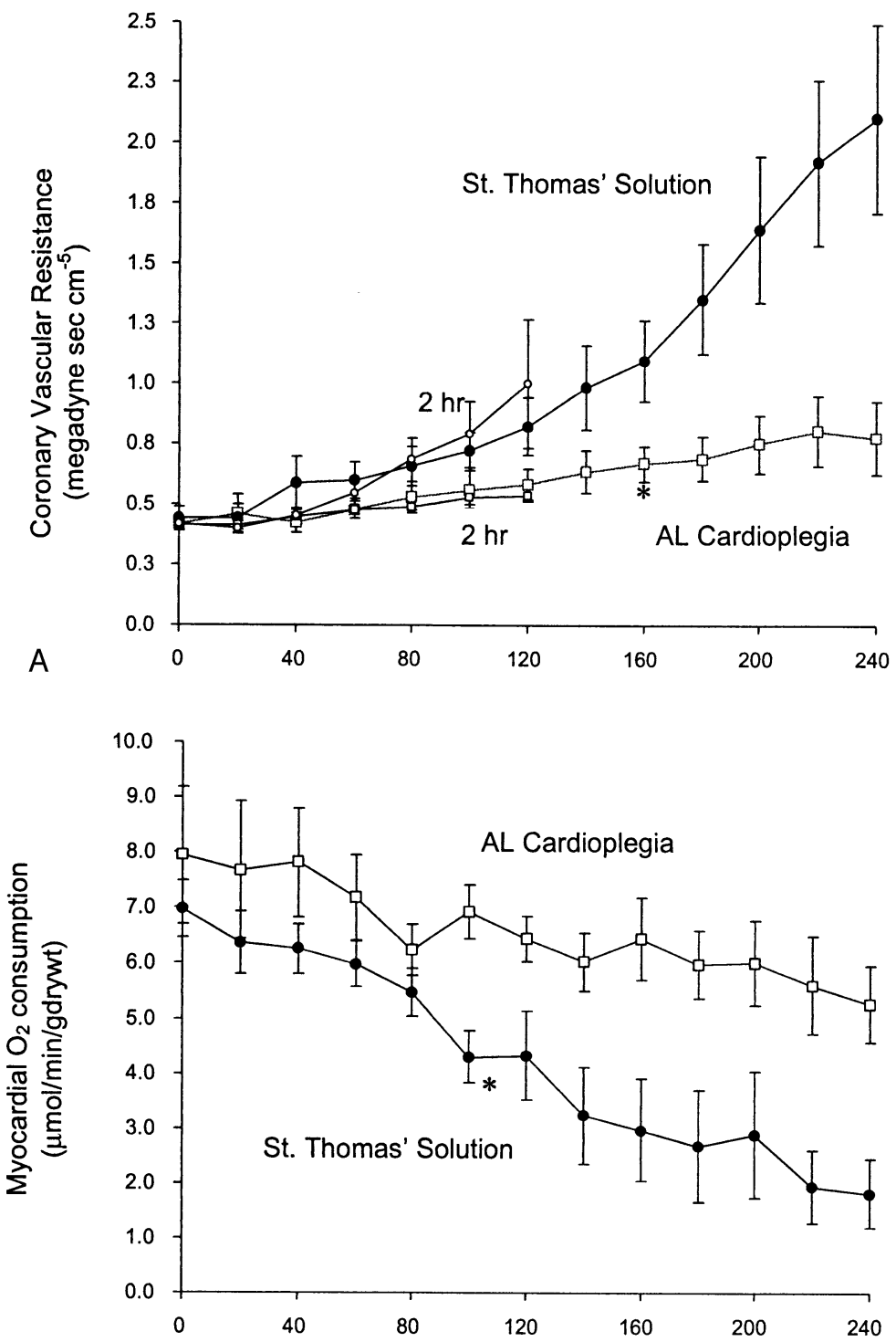

B

Time (min)

Figure 3. A, CVR during 2- and 4-hour arrest. B, Oxygen consumption during 2- and 4-hour arrest. CVR was calculated during the 2-minute cardioplegia delivery times every 18 minutes (see Figure 1). Values are mean \pm SEM and asterisk shows significance between the 2 cardioplegia groups from repeated-measures ANOVA $(P<$ .05). All statistical tests for the 2- and 4-hour AL and St Thomas' Hospital solution arrest protocols were performed separately. For clarity, only the 4-hour arrest data are presented for oxygen consumption and arrest time; no significant differences in the first $\mathbf{2}$ hours were found between the 2- and 4-hour arrest protocols.

through some unknown A1 receptor, ATP-sensitive potassium channel, and/or $\mathrm{Na}^{+}$fast channel interaction(s).

4. Superior arrest and protection may also relate to the coronary vasodilatory properties of adenosine and lidocaine, resulting in the reduced coronary vascular resistance and greater delivery of cardioplegic solu- tion (Figure 3). The lower coronary resistance in $\mathrm{AL}$ hearts was not due to reduced tissue edema $(88.7 \%)$ and its extravascular compression, nor was $\mathrm{St}$ Thomas' Hospital solution's higher resistance and poor performance due to increased edema (87\%). It is noteworthy that total tissue water in crystalloid perfused rat hearts range from $85 \%$ to $88 \%{ }^{24}$ and is 

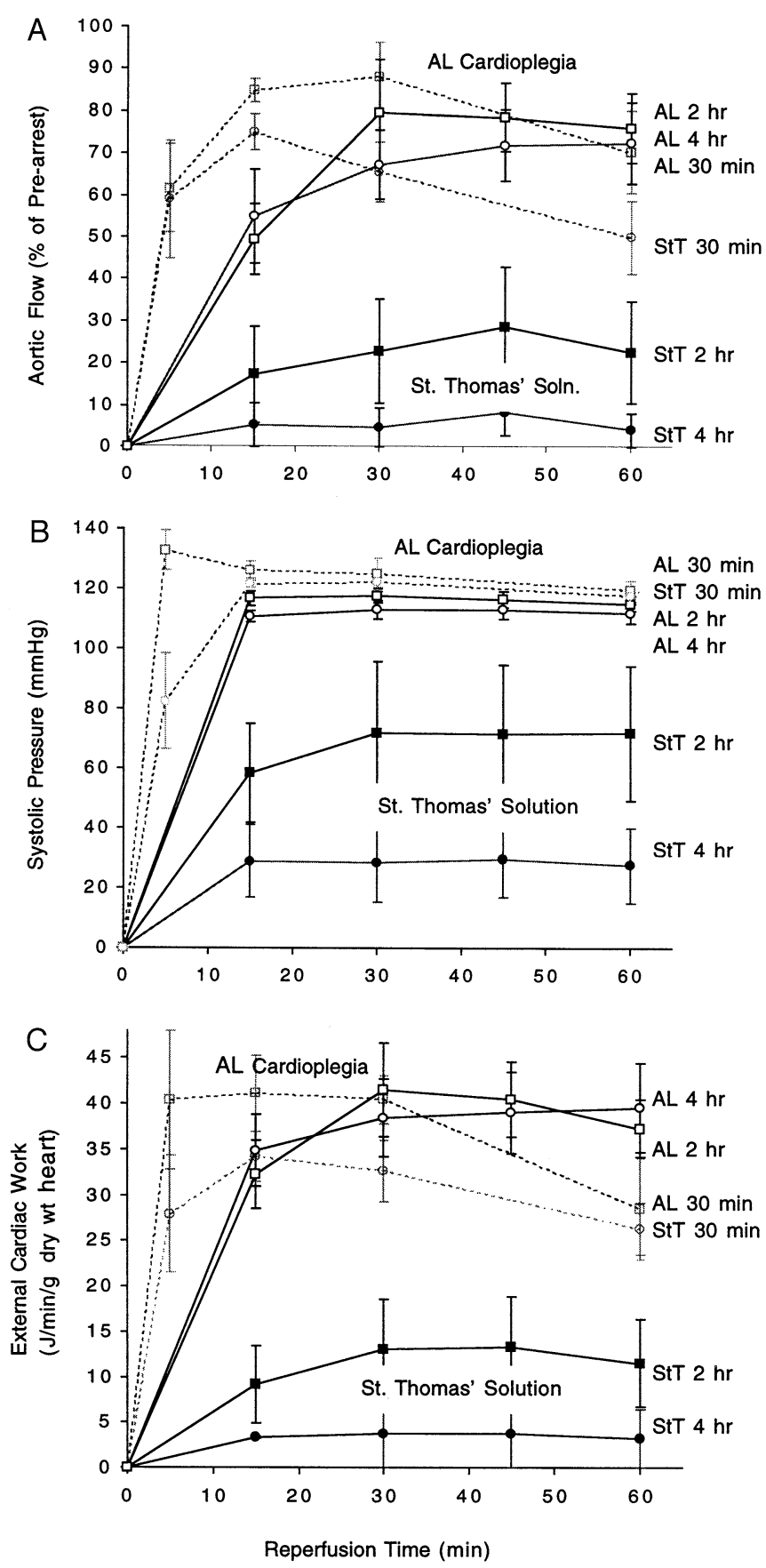

Figure 4. Aortic flow (A), systolic pressure (B), and external cardiac work (C) during the reperfusion period after 30-minute, 2-hour, and 4-hour arrest with AL cardioplegic solution and modified St Thomas' Hospital solution no. 2. Aortic flow is expressed as percentage of control at 5 minutes before arrest. Values are mean \pm SEM and asterisk shows significance between the 2 cardioplegia groups at different arrest times $(P<.05)$. For St Thomas' Hospital solution hearts, only $50 \%(4 / 8)$ and $14 \%$ (1/7) recovered aortic flow after 2 - and 4-hour arrest, respectively. The systolic pressures 5 minutes before arrest in the AL and St Thomas' Hospital solution hearts (in parentheses) for the 30-minute, 2-hour, and 4-hour groups were $128 \pm 3 \mathrm{~mm} \mathrm{Hg} \mathrm{(124} \pm 1.3 \mathrm{~mm} \mathrm{Hg}), 120 \pm 2 \mathrm{~mm} \mathrm{Hg}(121 \pm 3 \mathrm{~mm}$ $\mathrm{Hg})$, and $118 \pm 3.5 \mathrm{~mm} \mathrm{Hg}(122 \pm 2.4 \mathrm{~mm} \mathrm{Hg})$, respectively. The hydraulic work 5 minutes before arrest in the $\mathrm{AL}$ and St Thomas' Hospital solution hearts (in parentheses) for the 30-minute, 2-hour, and 4-hour groups were $42 \pm$ $5 \mathrm{~J} \mathrm{~min}^{-1} \mathrm{~g}^{-1}$ dry weight (43 $\pm 7 \mathrm{~J} \mathrm{~min}^{-1} \mathrm{~g}^{-1}$ dry weight), $41 \pm 2 \mathrm{~J} \mathrm{~min}^{-1} \mathrm{~g}^{-1}$ dry weight (38 $\pm 3 \mathrm{~J} \mathrm{~min}^{-1} \mathrm{~g}^{-1}$ dry weight), and $44 \pm 2 \mathrm{~J} \mathrm{~min}^{-1} \mathrm{~g}^{-1}$ dry weight (45 $\pm 2 \mathrm{~J} \mathrm{~min}^{-1} \mathrm{~g}^{-1}$ dry weight) $\mathrm{J} \mathrm{min}^{-1} \mathrm{~g}^{-1} \mathrm{dry}$ weight, respectively. 


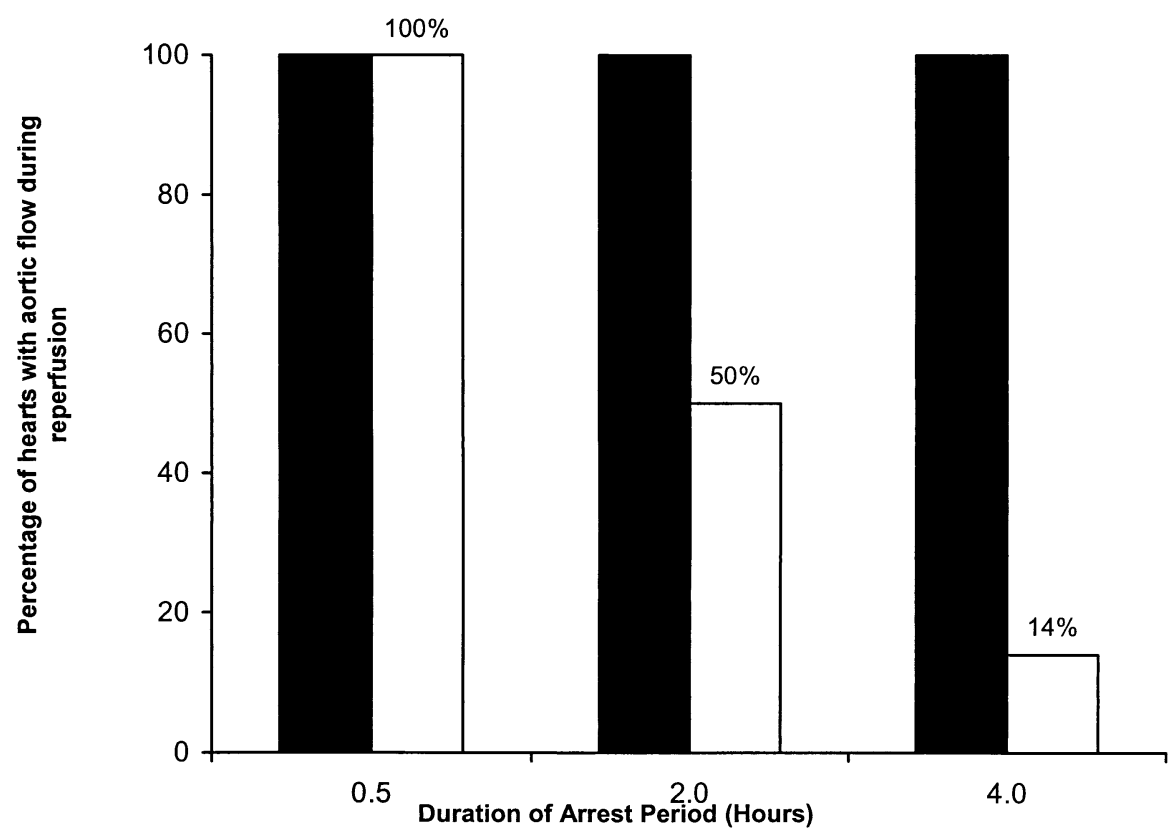

Figure 5. Percentage of hearts with aortic flow after 0.5, 2, and 4 hours of multidose AL and modified St Thomas' Hospital solution cardioplegia. Shaded areas depict AL-arrested hearts and unshaded areas are St Thomas' Hospital solution hearts. Failure to survive was defined as the inability of the heart to develop aortic flow against an afterload of $100 \mathrm{~cm} \mathrm{H}_{2} \mathrm{O}$ (see text).

significantly greater than in situ rat hearts $(79 \%) .{ }^{28}$ Perfused hearts undergo major redistributions of tissue water with the extracellular space increasing about 2 times the in situ value. ${ }^{24,28}$ Therefore, hearts treated with either AL or St Thomas' Hospital solution appeared to accumulate tissue water. Further studies are required to investigate the effect of AL cardioplegic soltuion on coronary blood flow and the distribution of water in the interstitial, extracellular, and intracellular compartments.

5. AL's superior protection may be associated with other compositional differences to St Thomas' Hospital cardioplegic solution. AL cardioplegic soltuion contains a "physiologic" nondepolarizing concentration of potassium similar to that concentration found in blood. Concentrations of potassium above $15 \mathrm{mmol} / \mathrm{L}$ have been linked to left ventricular dysfunction, which is more pronounced at higher temperatures. ${ }^{3,6-8,41}$ In 1991 Mankad and colleagues ${ }^{42}$ also reported that high potassium in St Thomas' Hospital solution or Bretschneider solution resulted in endothelial damage, and this deleterious effect was concentration-dependent. AL cardioplegic soltuion also has a lower "physiologic" concentration of magnesium $(\sim 0.5 \mathrm{mmol} / \mathrm{L})$, and although higher concentrations have been shown to be cardioprotective in hyperkalemic solutions, ${ }^{2}$ the lower concentration in AL solution did not appear to compromise function. In addition, superior protection and preservation of AL cardioplegia may be due to the presence of exogenous glucose $(10 \mathrm{mmol} / \mathrm{L})$. As indicated in Materials and Methods, we omitted glucose from the St Thomas' Hospital solution because Hearse and colleagues ${ }^{2,25}$ showed that its presence was detrimental to postarrest functional recovery, a concept that is reflected in the absence of glucose from commercially available Plegisol solution (Abbott Laboratories, North Chicago, Ill). However, preliminary studies show that under our experimental conditions the presence of $10 \mathrm{mmol} / \mathrm{L}$ glucose in St Thomas' Hospital solution did modestly improve aortic flow after 4 hours of arrest from $\sim 2$ to $8 \mathrm{~mL} / \mathrm{min}(\mathrm{n}=4)$ at 30- to 60-minute reperfusion (unpublished observations). In addition, the presence or absence of glucose did not alter the postcardioplegia recovery of function in the St Thomas' Hospital solution group relative to the AL group.

In conclusion, the polarizing combination of adenosine and lidocaine unifies the concepts of efficient cardiac arrest with potent myocardial protection from ischemic-reperfusion injury that are the attributes of the "ideal" cardioplegic solution, which is not embraced with the current potassiumand hypothermia-based cardioplegia strategies. The therapeutic efficacy of normothermic AL blood cardioplegia, including adenosine's stability, redosing requirements, and 
hemodynamic effects, is currently being investigated in larger animal models undergoing cardiopulmonary bypass.

We thank cardiothoracic surgeon Dr Benjamin P. Bidstrup for early discussions on clinical aspects of cardioplegic delivery and we especially thank Professor Jakob Vinten-Johansen for discussions on adenosine's broad-spectrum actions. G.P.D. would also like to thank the Queensland's State Government Department of Innovation and Economy for their continued support. G.P.D. dedicates this paper to his friend and research colleague Dr Ming-ta Huang, who died unexpectedly of complications after coronary artery bypass surgery in March 1999.

\section{References}

1. Buckberg GD. Myocardial protection: an overview. Semin Thorac Cardiovasc Surg. 1993;5:98-106.

2. Chambers DJ, Hearse DJ. Cardioplegia and surgical ischaemia. In: Sperelakis N, Kurachi Y, Terzic A, Cohen MV, editors. Heart physiology and pathophysiology. San Diego: Academic Press; 2001. p. 887-926.

3. Cohen NM, Damiano RJ, Wechsler AS. Is there an alternative to potassium arrest? Ann Thorac Surg. 1995;60:858-63.

4. Jayawant AM, Stephenson ER, Matte GS, et al. Potassium channel opener cardioplegia is superior to St. Thomas' solution in the intact animal. Ann Thorac Surg. 1999;68:67-74.

5. McCully JD, Tsukube T, Ataka K, Krukenkamp IB, Feinberg H, Levitsky S. Myocardial cytosolic calcium accumulation during ischemia/reperfusion: the effects of aging and cardioplegia. J Cardiothorac Surg. 1994;9:449-52.

6. Lopez JR, Jahangir R, Jahangir A, Shen WK, Terzic A. Potassium channel openers prevent potassium-induced calcium loading of cardiac cells: possible implications in cardioplegia. J Thorac Cardiovasc Surg. 1996;112:820-31.

7. Jayawant AM, Damiano RJ. The superiority of pinacidil over adenosine cardioplegia in blood perfused isolated hearts. Ann Thorac Surg. 1998;66:1329-36.

8. Suleiman MS, Halestrap AP, Griffiths EJ. Mitochondria: a target for myocardial protection. Pharmacol Ther. 2001;89:29-46.

9. Menasche P, Kevelaitis C, Grousset C, Piwnica A, Bloch G. Preconditioning with potassium channel openers. A new concept for enhancing cardioplegic protection. J Thorac Cardiovasc Surg. 1995;110: 1606-13.

10. Gross GJ, Auchampach JA. Role of ATP dependent potassium channels in myocardial ischaemia. Cardiovasc Res. 1992;26:1011-6.

11. Ducko CT, Stephenson ER, Jayawant AM, Vigilance DW, Damiano RJ. Potassium channel openers: Are they effective as pretreatment or additives to cardioplegia? Ann Thorac Surg. 2000;69:1363-8.

12. Hu K, Li G-R, Nattel S. Adenosine-induced activation of ATP-sensitive $\mathrm{K}^{+}$channels in excised membrane patches is mediated by PKC. Am J Physiol. 1999;276:H488-95.

13. Foker JE, Einziz S, Wang T. Adenosine metabolism and myocardial preservation. J Thorac Cardiovasc Surg. 1980;80:506-16.

14. Schubert R, Vetter H, Owen P, Reichart B, Opie LH. Adenosine cardioplegia. J Thorac Cardiovasc Surg. 1989;98:1057-65.

15. Vinten-Johansen J, Thourani VH, Ronson RS, et al. Broad-spectrum cardioprotection with adenosine. Ann Thorac Surg. 1999;68:1942-8.

16. Haworth RA, Goknur AB, Berkoff HA. Inhibition of Na-Ca exchange by general anaesthetics. Circ Res. 1989;65:1021-8.

17. Hearse DJ, O'Brian K, Braimbridge MV. Protection of the myocardium during ischemic arrest: dose response curves for procaine and lignocaine solutions. J Thorac Cardiovasc Surg. 1981;81:873-9.

18. Jovanovic A, Lopez JR, Alekseev AE, Shen WK, Terzic A. Adenosine prevents $\mathrm{K}^{+}$-induced $\mathrm{Ca}^{2+}$ loading: insight into cardioprotection during cardioplegia. Ann Thorac Surg. 1998;65:586-91.

19. Lasley RD, Mentzer RM. Protective effects of adenosine in the reversibly injured heart. Ann Thorac Surg. 1995;60:843-6.

20. Hollmann MW, Difazio CA, Durieux ME. Ca-signaling G-proteincoupled receptors: a new site of local anesthetic action? Reg Anesth Pain Med. 2001;26:565-71.

21. Cohen G, Feder-Elituv R, Lazetta J, et al. Phase 2 studies of adenosine cardioplegia. Circulation. 1998;98(Suppl II):II225-33.

22. Snabaitis AK, Shattock MJ, Chambers DJ. Comparison of polarized and depolarized arrest in the isolated rat heart for long-term preservation. Circulation. 1997;96:3148-56.

23. Asano M, Inoue K, Ando S, et al. Optimal temperature of continuous lidocaine perfusion for the heart preservation. Jpn J Thorac Cardiovasc Surg. 2003;51:1-9.

24. Masuda T, Dobson GP, Veech RL. The Gibbs-Donnan near-equilibrium system of heart. J Biol Chem. 1990;265:20321-34.

25. Hearse DJ, Stewart DA, Braimbridge MV. Myocardial protection during ischemic cardiac arrest. Possible deleterious effects of glucose and mannitol in coronary infusates. J Thorac Cardiovasc Surg. 1978; 76:16-23.

26. Neely JR, Rovetto MJ, editors. Techniques for perfusing isolated rat hearts. London, New York: Academic Press; 1975.

27. Taegtmeyer H, Hems R, Krebs HA. Utilization of energy-providing substrates in the isolated working rat heart. Biochem J. 1980;186:70111.

28. Dobson GP, Cieslar JH. Intracellular, interstitial and plasma spaces in the rat myocardium in vivo. J Mol Cell Cardiol. 1997;29:3357-63.

29. Altman PL, Dittmer DS, editors. Respiration and circulation. Bethesda (MD): Federation of American Societies for Experimental Biology; 1971.

30. Christoforides C, Laasberg LH, Hedley-Whyte J. Effect of temperature on solubility of $\mathrm{O}_{2}$ in human plasma. J Appl Physiol. 1969;26:56-60.

31. Kleber AG. Resting membrane potential, extracellular potassium activity, and intracellular sodium activity during acute global ischemia in isolated perfused guinea pig hearts. Circ Res. 1983;52:442-50.

32. Chambers DJ. Polarisation and myocardial protection. Curr Opin Cardiol. 1999;14:495-500.

33. Martynyuk AE, Seubert CN, Zima A, et al. Contribution of I(K,ADO) to the negative dromotropic effect of adenosine. Basic Res Cardiol. 2002;97:286-94.

34. Gross GJ, Fryer RM. Sarcolemmal versus mitochondrial ATP-sensitive $\mathrm{K}^{+}$channels and myocardial protection. Circ Res. 1999;84:973-9.

35. Grover GJ, Garlid KD. ATP-sensitive potassium channels: a review of their cardioprotective pharmacology. J Mol Cell Cardiol. 2000;32: 677-95.

36. Light PE, Kanji HD, Manning Fox JE, French RJ. Distinct myoprotective roles of cardiac sarcolemmal and mitochondrial KATP channels during metabolic inhibition and recovery. FASEB J. 2001;15:2586-94.

37. Sato T, Sasaki N, O'Rourke B, Marban E. Adenosine primes the opening of mitochondrial ATP-sensitive potassium channels: a key step in ischemic preconditioning? Circulation. 2000;102:800-5.

38. Krieg T, Qin Q, McIntosh EC, Cohen MV, Downey JM. ACh and adenosine activate PI3-kinase in rabbit hearts through transactivation of receptor tyrosine kinases. Am J Physiol. 2002;283:H2322-30.

39. Mubagwa K. Does adenosine protect the heart by acting on the sarcoplasmic reticulum? Cardiovasc Res. 2002;53:286-9.

40. Kambouris NG, Nuss HB, Johns DC, Marban E, Tomaselli GF, Balser JR. A revised view of cardiac sodium channel "blockade" in the long-QT syndrome. J Clin Invest. 2000;105:1133-40.

41. Ou R, Gavin JB, Esmore DS, Rosenfeldt FL. Increased temperature reduces the protective effect of university of Wisconsin solution in the heart. Ann Thorac Surg. 1999;68:1628-34.

42. Mankad PS, Chester AH, Yacoub MH. Role of potassium concentration in cardioplegic solutions in mediating endothelial damage. Ann Thorac Surg. 1991;51:89-93. 